FACTA UNIVERSITATIS

Series: Philosophy, Sociology, Psychology and History Vol. 19, N ${ }^{\circ} 1,2020$, pp. 45 - 59

https://doi.org/10.22190/FUPSPH2001045M

Original Scientific Paper

\title{
THE SOCIAL ROLE AND COMPETENCIES OF TEACHERS IN HIGHER EDUCATION BETWEEN THEORY AND TEACHING PRACTICE
}

UDC 316.64-057.875:378-057.175

\section{Suzana Marković Krstić, Lela Milošević Radulović}

University of Niš, Faculty of Philosophy, Department of Sociology, Serbia

\begin{abstract}
Starting from the fact that higher education is an activity of special social interest and the initiator of the development and improvement of society, in theory and teaching practice questions are often asked regarding the quality of higher education and the possibility of its improvement. The quality of higher education in terms of the increase in its effectiveness is one of the shared aims of the Bologna convention, that is, the current reform process in European countries. It is determined by the quality of the study programs and the quality of the teaching process, which requires a competent teacher, prepared for the process of innovating teaching plans and programs, and the realization and improvement of the teaching practice. Considering the social importance of education and teaching, research into the social group which performs work-related tasks in the educational process, as well as into the quality of the teaching itself, is of special importance. The paper presents the results of research regarding student perceptions of the characteristics of teachers manifested during the course of educational practice in higher education institutions, which were based on the following: the human, professional and pedagogical qualities of teachers, the quality of the university education/teaching process and learning outcomes/learning achievements (the prevalence of theoretical knowledge, practical application of knowledge, etc.). The aim of the paper is to, on the basis of three empirical studies, from a sociological standpoint evaluate the perception of the social role and competencies of teachers and the quality of university education from the viewpoint of the student youth(in 2009, 985 students from 30 colleges in Serbia were surveyed, in 2012, 2208 students of the University of Niš (818), University of Bitolj (804) and the University of Veliko Trnovo (586), and in 2019, 374 students from 13 faculties of the University of Niš). The empirical findings indicate that teachers are qualified professionals who lecture clearly, comprehensively and are able to emphasize the most important points, but that their lectures are still insufficiently interesting, and that they are often unjust and biased. Considering the noted differences between the competencies of teachers working in higher education settings, and the quality and outcomes of the
\end{abstract}

Received April 7, 2020 / Accepted June 8, 2020

Corresponding author: Suzana Marković Krstić

University of Niš, Faculty of Philosophy, Ćirila i Metodija 2, 18000 Niš, Serbia

E-mail: suzana.markovic.krstic@ filfak.ni.ac.rs 


\begin{abstract}
teaching/learning, "models" of teaching/learning have been proposed in this paper for each of the countries included in the study (Serbia, Macedonia, Bulgaria). Based on noted disparity between theory and teaching practice, the paper points to the need for new scientific research in the context of reform processes in higher education, with the continued redefinition of its goals and tasks with the aim of improving the quality of the teaching process and teaching practice.
\end{abstract}

Key words: university education, competencies of teachers, teaching practice, student youth

\title{
1. INTRODUCTION
}

Global social changes have led to an increase in the speed at which social subsystems are transformed, especially in the case of the educational subsystem (Parsons, 1961; Gidens, 2003) and the social role of teachers, as a socio-professional group which performs an educational function. Education for the 21st century has a deciding role not only for the development of the personality, but also in the development of the entire society, so what we are dealing with is the necessity of moving towards a "society of education", the creation of an educated society based on the acquisition, activation and application of knowledge (Delors 1996). A contemporary understanding of education and the social role of the teacher is the result of a different approach to the overall process of education and teaching, in whose realization teachers actively participate. Considering that contemporary educational processes develop in a variety of forms and are characterized by a high level of complexity, they cannot be reduced to only simple interactional relations between teachers and students. The role of the teacher in education changes significantly with the application of technical means in the teaching/learning process, with an emphasis on the development of habits and skills, ethical and other features of the personality. The new concept of education, through which the students become the subjects of their education and upbringing, the spreading of self-education and the more detailed preparation of the educational process in scientific and professional institutions have put the teacher in a completely new position. In that sense, the teacher is less a source of information, and is increasingly more the intermediary between students and knowledge which originates from various sources. The teacher more and more often takes on the role of an organizer (guide) of the students' work, their self-education, and the educational process in general.

The educational process requires a competent expert, aware of his responsibilities. On the attitude of the teacher and his activities depend, ultimately, the overall education and culture of the youth of a country, the fate of individuality, as well as the future of science and socio-economic development in society. The roles of a teacher in the educational process become increasingly complex, and the teachers' responsibility for the organization or learning and teaching increases. As a result, the responsibilities of the teacher are emphasized, as are the obligations of the bearers of the teaching profession, that is, the moral dimension of this profession. According to E. Durkheim, moral authority is the main feature of a teacher. A teacher should believe in his work, be aware of its importance, the importance of the mission he is carrying out. The teacher should, without any doubt, believe, not in himself, not in the higher values of his intelligence or his heart, but in the task itself, and greatness of his task. (...) He too is an organ of a massive moral body which stands above him: society (Durkheim 1981, 56). 
The contemporary approach to the social role of the teacher is the result of a different approach to educational activities and teaching, for whose realization the active participation of the teacher is necessary. These processes cannot merely be reduced to simple interactional relations between the teacher and the students, but instead are characterized by the high level of the complexity of the organization and interaction. In that sense, teachers have been given new, more numerous and more varied roles, as an addition to those which pertain to teaching and learning. Some of them include: being a friend, a confidant, one who facilitates the development of personality as a whole, one who transfers cultural values. Ivan Ivić and associates cite the numerous roles of a teacher, without determining the unique criterion of classification, but at the same time providing the all-encompassing nature of the professionally expected types of behavior of the teacher in terms of providing active teaching/learning: the role of a teacher, the role of a motivator, the role of an assessor, evaluator, the knowledgediagnostic role, the role of a regulator of social relations, the role of a partner in affective interaction (Ivić et al. 1997). In contemporary university education, teachers are more and more often performing the role of a consultant and organizer of their students' work and their self-education. When giving due consideration to the roles of the teacher in the educational process and in providing successful classes, as well as to the characteristics of education as a unique human activity recognizable as teaching (the work of a teacher), the more favorable and desirable features of teachers should be emphasized, as well as their necessary competencies.

Contemporary society is a society of knowledge, and requires constant learning and improvement. The basic assumptions for the development and improvement of society include competencies, and competent individuals represent a valuable human resource. That is why the analysis of the quality and type of knowledge which both young and adult individuals need for the future, that is, for a society of knowledge (Gardner 1993), and the reevaluation of the fundamental paradigms and starting points in organizing education, which strives to prepare an individual for a life and for work in the future, is of special scientific interest (Reardon 2010). In such a society education does not include only functional literacy and encyclopedic knowledge, but the acquisition of practical and applicable knowledge, as well as the development of the creative potentials of the individual. The society of knowledge has a higher dimension, not only a cognitive, but also a motor one, as well as a value dimension, which refers to familiarization and learning about basic human values. The key characteristics of society are freedom, pluralism, democracy, tolerance, peace, and nonviolent conflict resolution (Madows et. al. 1972). Accordingly, initiatives are set into motion for the research into quality of education, social relations among the participants in the educational process (teachers and learners/students), and the study and development of new characteristics of knowledge for the requirements of a new society. The goal of education in contemporary society is primarily the acquisition of knowledge and skills; however, we must never neglect the humanist goals of education, that is, the humanist dimensions of the education of young people in the context of contemporary social change (Marković Krstić \& Milošević Radulović 2016). E. Morin points out that a new educational paradigm is needed, one which should provide "a thought reform" $(2002,186)$ and an organization of the knowledge process in accordance with the needs of the new society.

The age of globalization is characterized by international connections, the strengthening of the role of international institutions, the dominance of knowledge and the rapid transfer of information from one end of the globe to another. The new stage of the scientifictechnological revolution, the formation of a new scientific map of the world, and the 
appropriate changes in scientific paradigms require changes in the sphere of education, primarily in terms of its content. "In this context, the high priority question that is posed is the one regarding the role of education, science and the university, not only in education, but also in the formation of views of the world and the political culture of a new generation [...] And that means that the key question is one regarding the educational policy of a society, since what depends on it is not only the quality of the professionalism of new generations, but also their cultural organization, view of the world, national identity, and a global culture of peace, that is, responsibility for the development, peace and future of humanity" (Mitrović 2019, 148). In the context of complex and rapid social changes in all spheres of life, the responsibility of the university is based on providing a quality education for highly professional individuals, as well as on developing social responsibility.

The quality of education on any level, including the tertiary one, depends on numerous subjective and objective factors, among which the quality of the work done by teachers, that is, their competencies, holds a special place (Alibabić 2010, 79). While the material task of education refers to the process of acquiring knowledge on the objective reality which is studied as part of certain courses, its functional task is the development of various abilities (intellectual, social, practical, etc.), that is, the development of psycho-physical and social functions of young people. The quality of the teaching/learning process can be evaluated based on various indicators: competencies of the teachers who are mediators between the students and the knowledge, the teaching/learning methods, and the quality of the students' achievements (Marković Krstić \& Milošević Radulović 2014).

This paper will present the results of empirical studies which refer to the social role and competencies of higher education teachers, the quality of the courses/learning at the university level, the quality of learning outcomes, and the contribution and significance of a university education (the outcome of education). This sort of approach to the study of university teaching practices in Serbia, Macedonia, and Bulgaria will enable us to view some of the aspects of the quality of higher education and to realize the requirements of the Bologna reform process in the teaching practices in higher education. The teachers with its human, professional and pedagogical qualities, this group directly contributes to the quality of the educational process, and represents the most important available resource of the educational system. The social role of teachers is becoming increasingly more complex, and their responsibility for the organization of learning and teaching is increasing. The focus of work done as a part of the educational process is no longer the transfer of knowledge, but the organization of learning with the maximum use of new sources of knowledge, as well as the practical application of any acquired skills. Further research should study the social role and competencies of the teachers, but also the quality of knowledge which the students are acquiring, and the possibility of applying this knowledge in practice.

\section{THE METHOD}

The subject matter of this paper is the student perception of the social role and competencies of higher education teachers, and the quality of the university teaching/ learning processes, as well as the quality of the learning outcomes in the teaching practices in higher education (in Serbia, Macedonia, and Bulgaria). The competencies of teachers and the quality of university education are evaluated in the context of the implementation of the requirements of the current reform process in higher education (the Bologna reform process). 
The paper is based on the results of three empirical studies: 1) "The social origin of students, success in education, and the choice of study programs in colleges of professional studies" (in 2009, 985 students from 30 colleges of professional studies in 28 cities in Serbia were surveyed), 2) "The cultural orientation of actors, interethnic relations, national identities, and the culture of peace in the Balkans"1, (in 2012, 2208 students were surveyed - 818 from the University of Niš - 804 from the University of Bitolj and 586 from the University of Veliko Trnovo), and 3) "The social origin of students, success in education, and choice of study programs at university" (in 2019, 374 students from 13 faculties of the University of Niš were surveyed). Thus, the study included 3567 students (985 students of colleges of professional studies in Serbia, 2208 undergraduate university students from Serbia, Macedonia, and Bulgaria, and 374 undergraduates from Niš). The aim was to study the individual qualities/ competencies of the teachers (human, professional, and pedagogical), the prevalence of traditional and modern teaching methods and learning outcomes as a part of university courses, as well as to evaluate the differences in the quality of the teaching practices in the universities included in the survey (a description and comparison). The tasks were to determine: a) the prevalence of individual teacher competencies; b) which teaching methods were dominant in university teaching practices; c) the prevalence of learning methods (mechanical learning, learning with understanding, problem learning, creative learning); d) whether the school system enables the development of skills which are needed for further education and professional development, the practical application of knowledge, the development of critical thinking, the adoption of knowledge and development of skills in accordance with modern technological advancements, the development of abilities for tolerant and nonviolent conflict resolution methods, and the adoption of knowledge regarding the cultural and national identity of one's own people; and e) whether there are any significant differences in the way in which discipline is maintained during class, any differences in the applied teaching methods, learning methods, and the learning outcomes at the universities in Serbia, Macedonia, and Bulgaria. The data were compiled during the course of a student survey, and were processed using the SPSS data analysis program. Of the research instruments, specially designed questionnaires for students attending colleges of professional studies and university students were used.

\section{RESEARCH RESULTS - ANALYSIS AND INTERPRETATION}

1) The social role and competencies of higher education teachers - from theory to teaching practice. Teaching as a pedagogical category is based on two processes: learning - the activity undertaken by the students and teaching - the activity undertaken by the teachers. Considering that they take an active part in the teaching process (students and teachers), the interaction and communication among them classifies teaching among the most widespread of social processes. That is why analyzing the role of a teacher in the realization of higher quality (more successful) teaching and the encouragement of the further development of students carries great significance. Recently, attempts have been

\footnotetext{
${ }^{1}$ The research was carried out as part of the project Tradition, modernization and national identities in Serbia and the Balkans in the process of European integrations (179074D), realized by the Centre for Sociological Research at the Faculty of Philosophy of Niš (2010-2019), and financed by the Ministry of Education, Science and Technological Development of the Republic of Serbia. The authors of this paper were members of the research team involved in the project.
} 
made to base the teaching process on curriculum theory, constructivism (Reich 2008), and a competency approach to the outcomes of the educational process. The competency-based approach includes attempts to express learning outcomes as competencies which will help an individual to discover new knowledge, and foster the use of existing knowledge or management of existing knowledge and technologies. At the same time, competencies are thought to include professionalism, and the skills one has at their disposal, that is, authority and possession of a license to perform certain jobs (Anderson and Krathwool 2001). Competencies, in addition to theoretical knowledge and understanding, also include the practical application of knowledge on how to act and how to co-exist with others in the social context (Macanović 2019). The teacher has a responsible task of preparing students for life and professional work, of mediating between students and the knowledge which originates from various sources. As pointed out by Drucker (1985), knowledge is a tool and a product, it is discovered and used to increase productivity, but also for personal promotion. For the successful realization of teaching, certain teacher competencies are necessary - professional, pedagogical, communicative, social-humanist. However, for doing high quality work, a teacher's competencies are not sufficient, their personal and human qualities are also needed (Marković 2008, 151). Among the characteristics which are significant for the work of teachers, the following could be singled out: the personality traits of teachers (humanity and kindness, fairness, integrity, a fondness for the students, openness, a sense of humor, politeness, trust in the students); professional knowledge and skills (knowledge of the profession and of teaching practices, lecturing abilities); and organizational-communicative skills (democratic guidance of the students, taking student opinions into consideration, empathy, encouragement of students, stimulating cooperation between students, engaging in a dialogue with the students) (Trnavac \& Đorđević 1995, 146).

In previous studies which had focused on the learner's evaluation of the features of teachers (Jersild), it was determined that students prefer teachers with the following features: 1) human qualities (politeness, cheerfulness, unaffectedness, sociability, in a good mood, with a sense of humor); 2) qualities which refer to the attitude of the teacher towards the field of study (just, reliable, disciplined, unbiased); 3) physical qualities (physical attractiveness, a pleasing voice, neatness, youthfulness, good health) and 4) teaching qualities (a good working knowledge of the profession, a helpful disposition towards students, behavior in the interest of the students, an interesting individual, is able to interest students, can teach clearly, concisely and is able to emphasize everything that is important) (Acigan 1979, 4546). A study of the features of university instructors which was carried out by B. Đorđević and J. Đorđević is one of the few whose results have focused attention on numerous relevant features on which the success of the higher education teaching process depends. The results of this research have shown that the desirable features for the teaching process, in addition to the professional nature of the teacher - which refers to the teachers' competencies, and in addition to the personality features of the teacher, include communication with the students $(26,46 \%)$ and the pedagogical features of the teachers $(22,35 \%)(1992$, p. 111-112), which represent teaching competency. Such findings support the call for a systematic solution for the continued development of the teaching competencies of university educators (according to Alibabić 2010, 81).

During the course of research on the quality of teaching and the characteristics of higher education teachers working in colleges of professional studies in Serbia (30 higher education institutions; 2009), results were obtained which pertain to the human, professional and pedagogical qualities/competencies of the teachers (Graph 1). 


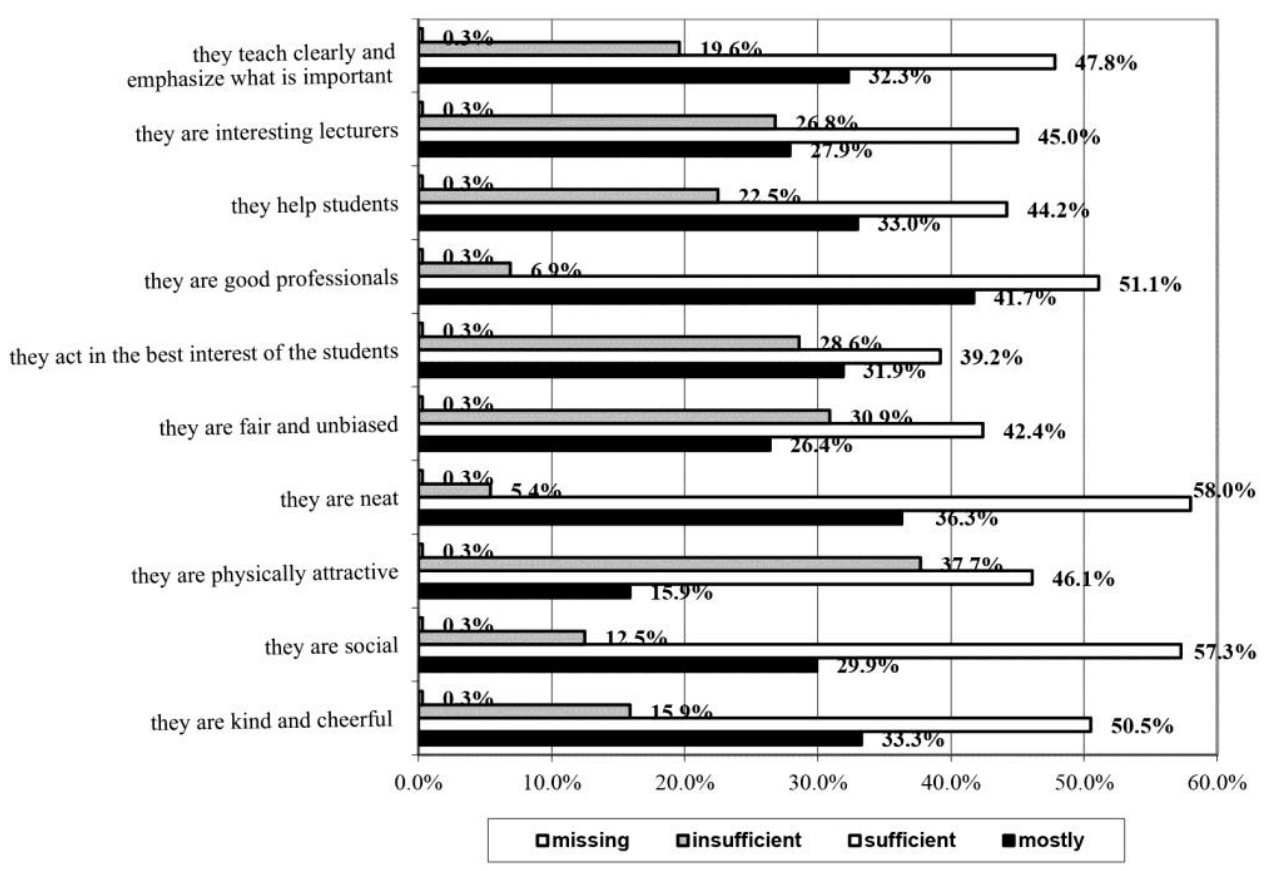

Graph1 Teacher qualities based on the evaluation of students attending universities of professional studies in Serbia

Students at the universities of professional studies rated one of the teaching qualities the highest - teachers are mostly good professionals $(41,7 \%)$, of the physical qualities teachers are mostly neat (36,3\%), and of the human qualities - teachers are mostly kind and cheerful $(33,3 \%)$. Thus, the majority of students confirmed that their educators are good professionals. That was at the same time also the highest percentage of obtained positive responses compared to the other studied features/qualities of the teachers.

The lowest grades the students gave to their teachers were mostly for their physical qualities - insufficiently physically attractive $(37,7 \%)$, for the qualities of teachers which refer to their attitude towards in-class discipline - insufficiently fair and unbiased (30,9\%), teaching qualities - insufficiently act in the best interest of the students $(28,6 \%)$ and are not sufficiently interesting lecturers $(26,8 \%)$. Most of the student population noted bias on the part of the teachers, that is, point out that students are not treated equally, "that there is always someone to whom the rules do not apply", "who is privileged", and "who gets off easy". The most frequently pointed out negative features of educators included: ex cathedra lecturing, lectures that students do not find interesting, the absence of communication with students, that is, the absence of contemporary teaching methods, not adhering to the opinions of students and the like. We can note a discrepancy between the data which refer to how interesting the lecture is (an almost equal ratio of the highest positive, 27,9\% and negative grades, 26,8\%) and the clarity and conciseness of the lectures (the highest positive grade 32,3\%, and negative grade, $19,6 \%$ ), which might indicate that the students do not consider the lectures particularly interesting, even though they are clear and understandable. 
The research results (from 2019, Graph. 2), which in part refer to the student evaluation of the university teaching practices at 13 faculties of the University of Niš, indicate a certain overlap with the results of previous studies in the case of certain qualities of the teachers: the human qualities of the teachers (sociability, 71,4\%), professional competencies (professionalism, 81,8\%) and pedagogical ones (they lecture clearly and emphasize what is most important, $69,8 \%$ ). The negative evaluations of the students refer mostly to teaching competencies (their lectures are not interesting, 43\%) and pedagogical ones (they are unfair and biased, 38\%).

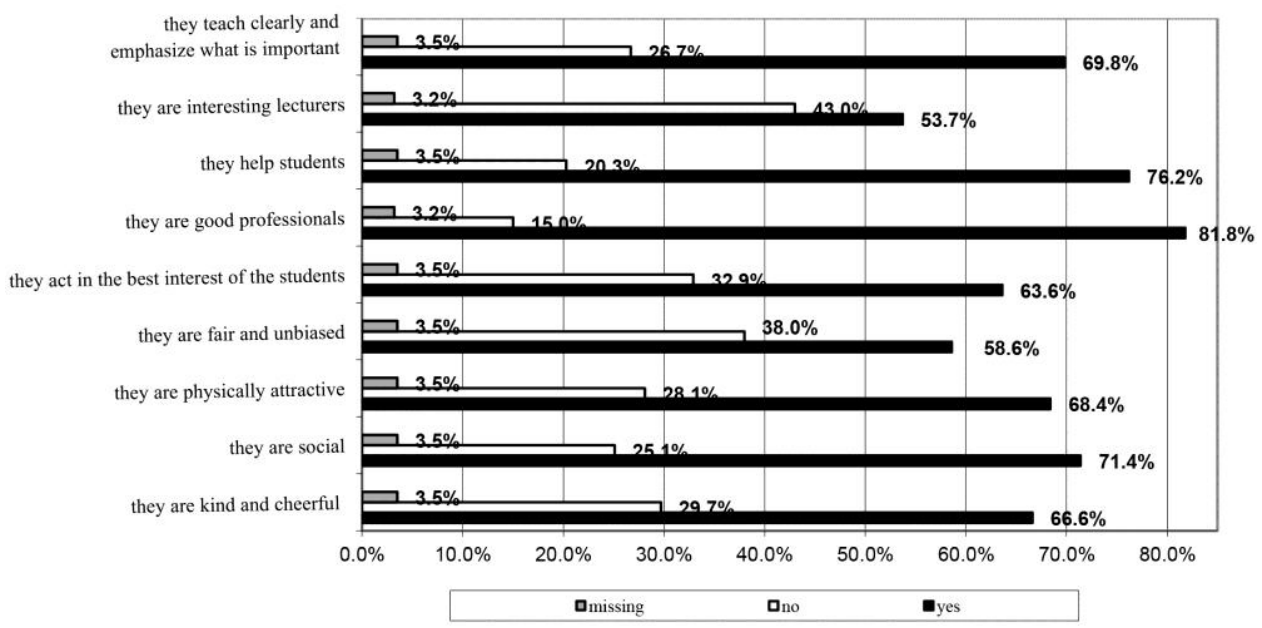

Graph 2. Teacher qualities based on the evaluation of students of the faculty of the University in Niš

The most frequently pointed out negative characteristics which refer to the lecturing of teachers were: ex cathedra lecturing, the absence of communication with the students, the absence of contemporary teaching methods, not taking into consideration the opinions of students, etc. Empirical findings of both studies indicate the discrepancy between the studied human qualities, teaching and pedagogical competencies of the teachers, as well as the discrepancies between the requirements made in pedagogical science and the practical activities of the teachers, that is, that the students, even though the teachers' lectures are clear and understandable, still consider them to be uninteresting, and that the teachers are social, but often unfair and biased.

These results indicate that essential changes are required regarding teaching competencies, which implies changes in higher education policies, and includes permanent improvement on the part of the teachers, and the adequate evaluation of all their competencies when hiring and offering promotions. Š. Alibabić points out that at universities abroad, the evaluation of teaching competencies is mostly standardized, while in our country there are no standards for the evaluation of teaching competencies, which leaves room for complete subjectivity, unlike in the case of the evaluation of the results of scientific-research work which is very objectively manifested by means of coefficients of scientific competence. The author believes that this may be the reason behind the greater dedication of teachers to scientific-research work than to 
teaching, and that the acquisition and development of teaching competencies should to some extent be obligatory. These findings are of great importance for practical activities, since, as the author states, they could prove to be a reference point in higher education policy, with essential and formal implications for the quality of the teaching process, the organization of education, and the further improvement of university teachers, as well as the objectivization of criteria in the process of election and re-election of teachers $(2010,86,98)$. In that sense, attention should be focused not only on the evaluation of the effects of the realized or commenced educational reforms, but also the evaluation of the level of provision of assumptions which are necessary for the successful realization of the reform processes, since in numerous environments educational reforms "do not work" precisely because no previous adequate preparations of the system for the ensuing changes have been made (for more details see Hebib 2019, 186).

2) The quality of university teaching/learning - from traditional to modern methods of teaching/learning. The quality of a university education is founded both on the competencies of the teachers which enable them to carry out teaching activities at higher education institutions, and the learning methods and educational outcomes on the part of the students. Teaching is the most organized system of education, since the most standardized, most systematic and most intense education takes place during this process. The teaching process is focused on the acquisition of knowledge of the objective reality which is studied as a part of certain courses, and its function is the development of numerous and diverse abilities (intellectual, social, practical and the like), that is, the development of psychophysical and social functions of young people. Class modernization is not only reflected in the introduction of new courses, but also in the increase of the prevalence of active participation on the part of the students, and team, or group forms of work as opposed to the frontal kind (shared work with all the students), and lecturing (verbal), or traditional classes. Traditional classes involve the student only as a passive recipient of certain content and information, and the teacher as the main source of knowledge. Learning is mostly based on the adoption and reproduction of certain knowledge which does not require great cognitive ability on the part of the students, and where verbalism is pronounced. The basic direction of communication is between the teacher and the student. However, learning includes not only the adoption of knowledge, but also skills and other competencies needed for the job market and everyday life. As a result, the modernization of teaching is needed, which includes the preparation of students for independent work, group, and team work. The modernization of university education includes intense interaction and multiple forms of communication in the teaching process, which require an interactive and flexible teacher. The role of the teacher as a moderator in the teaching process in higher education has undergone significant changes, so that the goal is not the mediation between knowledge and the students, but the teaching of skills which include setting certain goals, structuring class time, and balancing between personal aspirations and objective conditions (Trivunović 2017, 126).

The results of research carried out in 2012 (2208 students of the University of Niš, University of Bitolj, and University of Veliko Trnovo) have shown which teaching methods are dominant in university education in Serbia, Macedonia, and Bulgaria, and how teachers maintain discipline in class. 
Teachers mostly maintain discipline in class through interesting lectures, and this modus is most prevalent in Bulgaria $(49,2 \%)$. The second ranked modus is the participation of students in class (group work, discussions, debates, presentations), which is also most prevalent in Bulgaria (37,8\%). Strictness is mostly used to maintain discipline in class in Macedonia (31,2\%), and least of all in Bulgaria (13,0\%) (Graph 3).

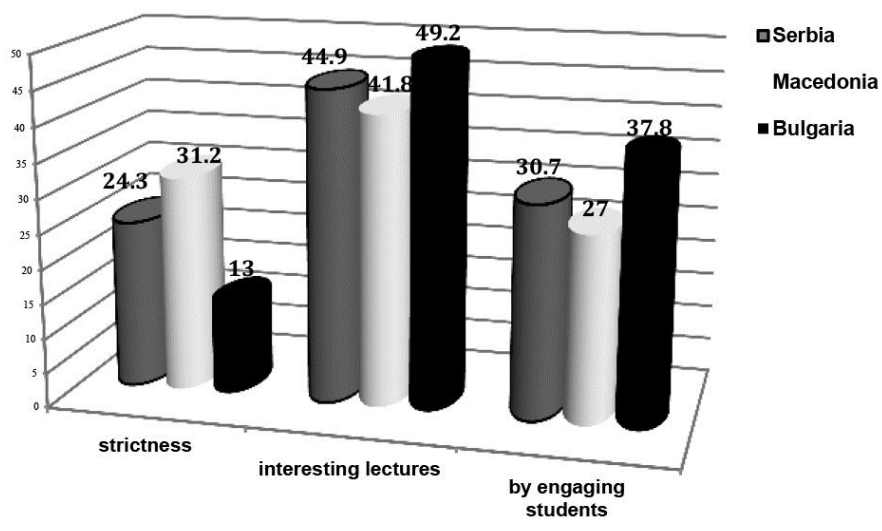

Graph 3 Modus of maintaining order and discipline in class

During the research, we also asked questions which refer to the prevalence of certain forms of education as part of the university education in Serbia, Macedonia and Bulgaria: is there a greater prevalence of traditional teaching forms or elements of modern interactive and problem teaching, as well as which teaching methods are predominantly found (monologue, dialogue, the discussion method).

The research results which refer to the teaching methods indicate that even today some of the most current problems are the same ones which higher education faced even prior to the implementation of the Bologna reform process in Serbia, Macedonia, and Bulgaria (traditional lecture method of teaching, verbalism, the lack of or insufficient prevalence of problem teaching, dialogue or debate).

Students of the three universities answered the posed question of how most teachers present a new unit by stating that most of their teachers lecture while they listen, which confirms the still dominant traditional/lecture method of teaching. Namely, 63,6\% of the surveyed students in Serbia, 47,6\% in Macedonia, and 42,5\% in Bulgaria have confirmed that their teachers mostly lecture while they listen. That their teachers talk to them, explain the material, and cite examples was indicated by $34,2 \%$ of the students in Serbia, 46,5\% from Macedonia, and 53,6\% from Bulgaria. The research results indicate that Serbia has the lowest, and Bulgaria the highest prevalence of modern teaching methods, despite the implementation of the Bologna reform process, which imposes the need for new reform solutions in higher education (Graph 4). 


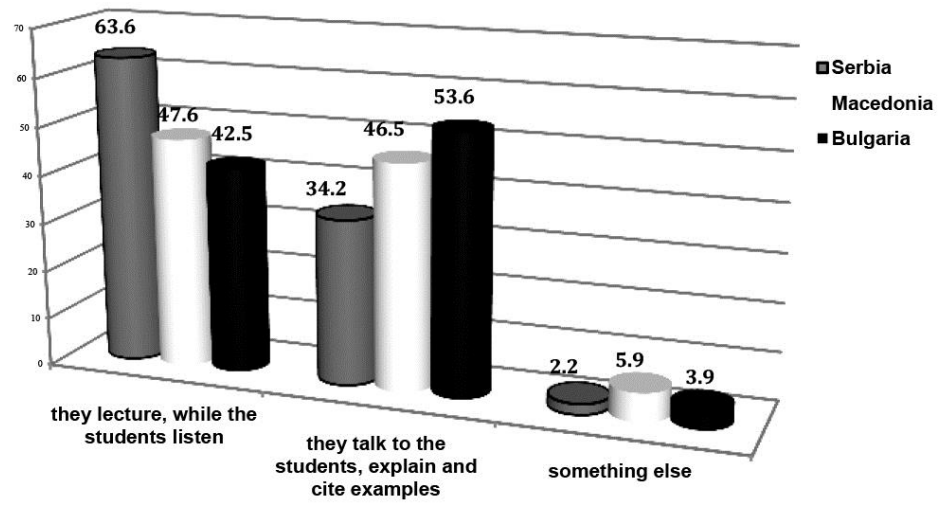

Graph 4 Teaching methods used during the presentation of a lesson

Even though the teaching/learning methods are combined in the same process, at this level of analysis we present results which refer to learning methods (different ways that students work, both in the teaching process, and as a part of their independent work). An adequate choice of learning methods contributes to the improvement in the quality of learning, that is, a better understanding of the content, and more successful learning. In that sense, we studied whether and to what extent we find the following learning methods: mechanical learning, learning with understanding, problem learning and creative learning as part of the university education process in Serbia, Macedonia and Bulgaria. A comparison of the research results indicates significant differences between the universities when it comes to learning methods: the greatest prevalence of mechanical learning (by heart) is in Serbia (a lot 54,8\%), and the lowest in Bulgaria (not at all 39,0\%); the greatest prevalence of learning with understanding (citing examples and applying acquired knowledge) is in Bulgaria $(60,9 \%)$, and the lowest in Macedonia (10,1\%); the greatest prevalence of problem learning (learning by solving problems) is in Bulgaria $(31,1 \%)$, and the lowest in Serbia $(22,1 \%)$; the greatest prevalence of creative learning (creating something new, for example computer programs, or drafts of new laws, the design of questionnaires) is in Bulgaria $(34,1 \%)$, and the lowest in Serbia $(36,5 \%)$. The presented research results indicate a positive trend in the application of certain learning methods, which is manifested in the form of a greater prevalence of interactive, modern methods of learning at certain universities (in Bulgaria), but also negative tendencies in teaching at higher education institutions in Serbia included in the survey (a greater prevalence of mechanical learning, and a lower prevalence of problem learning, and learning with understanding).

Considering the noted tendencies in the sphere of learning and teaching at various universities (the learning method, the teaching method), changes and the acceptance of innovations in the teaching process in higher education institutions is a necessary change that should not be delayed, and not something merely declarative and a formal obligation.

3) The outcomes of learning/achievements in learning - from theoretical knowledge to the practical application of knowledge. When it comes to the quality of education, it is very important to view learning outcomes/achievements, that is, the teleological side of education. That is why it was important to evaluate the opinions of students as to what the educational system in their country, and to which extent, enables them to do. A 
comparison and analysis of the research results indicate the existence of similarities in the prevalence of certain learning outcomes when it comes to particular countries, but also the existence of significant differences between the universities included in the research.

Table 1 Learning outcomes/achievements in the learning process of university students in Serbia, Macedonia and Bulgaria (\%)

\begin{tabular}{llccc}
\hline Learning outcomes/achievements & & Serbia & Macedonia & Bulgaria \\
\hline \multirow{2}{*}{ Knowledge and skills which are needed for the } & None & 11,4 & 23,2 & 9,3 \\
further education and professional development & A little & 66,8 & 59,6 & 61,2 \\
& Extensive & 21,7 & 17,2 & 29,5 \\
\hline \multirow{2}{*}{ Theoretical knowledge } & None & 5,3 & 14,2 & 5,0 \\
& A little & 27,6 & 45,4 & 39,9 \\
& Extensive & 67,1 & 40,3 & 55,1 \\
\hline \multirow{2}{*}{ Practical applicability of the knowledge } & None & 26,7 & 24,2 & 21,7 \\
& A little & 63,3 & 54,1 & 61,6 \\
& Extensive & 9,9 & 21,7 & 16,7 \\
\hline \multirow{2}{*}{ The ability to think critically } & None & 20,4 & 23,1 & 16,8 \\
& A little & 64,9 & 57,7 & 64,3 \\
& Extensive & 14,7 & 19,2 & 18,9 \\
\hline
\end{tabular}

Based on the responses of the students attending universities included in the study (Table 1), in Serbia the school system to the greatest extent enables the acquisition of theoretical knowledge (extensive 61,7\%), while to the least extent enables the practical application of knowledge (none 26,7\% and a little 63,3\%). In addition, the school system in Macedonia, in the opinion of the students, to the greatest extent enables the adoption of theoretical knowledge (extensive 40,3\%), and to the least extent the acquisition of knowledge and skills which are needed for further education and professional development (a little 59,6\% and none $23,2 \%$ ). The school system in Bulgaria, in the opinion of the students of the University of Veliko Trnovo, to the greatest extent enables the adoption of theoretical knowledge (extensive $55,1 \%$ ), and to the least extent enables the practical application of knowledge (a little 61,6\% and none $21,7 \%$ ). Thus, in the opinion of the students, the school system enables: the adoption of knowledge and development of skills which are needed for the further education and professional development the most in Bulgaria (extensive 29,5\%), and the least in Macedonia (none 23,2\%); the adoption of theoretical knowledge the most in Serbia (extensive 31,7\%), and the least in Macedonia (none 14,2\%); the practical application of knowledge the most in Macedonia (extensive 21,7\%), and the least in Serbia (none 26,7\%) and the development of the ability to think critically the most in Bulgaria (extensive 18,9\% and none 16,8\%), and the least in Macedonia (none 23,1\%).

The obtained results indicate positive tendencies in the school systems of certain countries, considering the fact that the students confirmed the existence of most of the cited and expected learning outcomes, that is, achievements in learning (Bulgaria). However, we can note a greater prevalence of theoretical knowledge in relation to the practical application of knowledge in certain universities (in Serbia and Bulgaria). This segment of the research results can serve as a closing argument which emphasizes the need for learning outcomes to be focused more in the direction of encouraging practical application of knowledge, that is, that the reform processes should continue so that a more complete and effective realization of the set educational goals could be achieved. 


\section{CONCLUSION}

Based on the analysis and comparison of the research results, which refer to teacher competencies in higher education and the quality of the teaching/learning, as well as the teaching/learning outcomes, certain "models" of teaching/learning can be formed for every country included in the survey.

Teachers in Serbia mostly lecture, and the students listen (a greater prevalence of the monologue method compared to Macedonia and Bulgaria); mechanical learning is more prevalent than in Macedonia and Bulgaria; the school system enables the development of critical thinking to a smaller extent than in Bulgaria, and enables the practical application of knowledge to a smaller extent than in both Bulgaria and Macedonia. The cited characteristics of the teaching/learning indicate the great prevalence of elements of the traditional in higher education teaching in Serbia. Research results indicate that the students of colleges of professional studies in Serbia and students of the University of Niš ranked as highest one of the human qualities of teachers - sociability, of the professional competencies - that the teachers are mostly experts in their respective fields, and of the pedagogical ones - mostly that they teach clearly and emphasize what is most important. The unsatisfactory evaluations on the part of the students mostly refer to pedagogical competencies - unfair and biased and educational ones - their lecturing method is not interesting enough. Teachers in Macedonia mostly maintain discipline during class through interesting lectures, and then by strictness (more so than in comparison to Serbia and Bulgaria); they talk more to their students, explain and cite examples more than the teachers in Serbia, but less than the teachers in Bulgaria; there is a greater prevalence of problem and creative learning than in Serbia, but lower than in Bulgaria, while learning with understanding is much less present than in both Bulgaria and Serbia; there is a lower prevalence of mechanical learning compared to Serbia, but a greater one compared to Bulgaria; the school system to a greater extent enables the practical application of knowledge compared to both Serbia and Bulgaria, and to a greater extent enables the development of critical thinking than in Serbia. These results indicate the prevalence of elements of the traditional and elements of the modern in university education in Macedonia. In Bulgaria teachers to a great extent give interesting lectures, engage their students during class (group work, discussions, debates, presentations) and talk to students, explain and cite examples (a greatest prevalence of the discussion method when compared to Serbia and Macedonia); there is a greater prevalence of learning with understanding, problem and creative learning compared to Serbia and Macedonia; the school system to the greatest extent, more so than in Serbia and Macedonia, enables the development of critical thinking. Thus, most of the indicators point to the great prevalence of elements of the modern in university education in Bulgaria.

The empirical findings indicate that in Serbia, Macedonia, and Bulgaria, it is necessary to intensify the process of modernization of the educational system, so as to overcome the noted weaknesses, and to realize the more successful application of theoretical knowledge in teaching practice. Considering the noted discrepancy between pedagogical theory and practice, that is, the insufficient application of theoretical knowledge in the teaching practice, new research is necessary. This research should focus on the study of the quality of teacher knowledge regarding the teaching and educational process, on the analysis of the ways in which this knowledge is applied in practice, and on the recognition of those factors which hinder the more complete connection between the theoretical knowledge of the teacher and their practical work, with the aim of realizing high quality classes. 


\section{REFERENCES}

Acigan, Lj. "Problem podobnosti za nastavnički poziv". U Savremene koncepcije i perspektive obrazovanja nastavnika. Novi Sad: Pedagoški zavod Vojvodine, 1979.

Alibabić, Š. "Univerzitetski profesor: naučnik i/ili nastavnik”. Andragoške studije 2 (2010): 79-100.

Anderson, W. L. and R. D. Krathwool. A Taxonomy for Learning, Teaching and Assessing (A Revision of Bloom's Taxonomy of Educational Objectives). New York: Longman, 2001.

Drucker, P. F. Innovation and Entrepreneurship: Practice and Principles. New York: Harper \& Row, 1985.

Delors J. Obrazovanje - skrivena riznica. Beograd: Ministarstvo prosvete Republike Srbije, 1996.

Durkheim, E.Vaspitanje i sociologija. Beograd: Zavod za udžbenike i nastavna sredstva, 1981.

Đorđević B. \& J. Đorđević. Svojstva univerzitetskih nastavnika. Beograd: Institut za pedagogiju i andragogiju Filozofskog fakulteta, 1992.

Ivić, I. et al. Aktivno učenje. Beograd: Institut za psihologiju, Filozofski fakultet, 1997.

Parsons, T. „The School Class as a Social System“. In Education, Economy and Society. Glencoe: Free press, 1961. Gardner, H. Multiple Intelligences: The Theory in Practice. New York: Basic Books, 1993.

Gidens, E. Sociologija. Beograd: Ekonomski fakultet, 2003.

Hebib, E. "Reforma obrazovanja kao proces promena u cilju razvoja". U Obrazovna politika i praksa: u skladu ili u raskoraku?, 182-188. Beograd: Filozofski fakultet Univerziteta u Beogradu, Institut za pedagogiju i andragogiju i Pedagoško društvo Srbije, 2019.

Macanović, N. "Kompetencije i društvo znanja". U Društvo znanja, 7-19. Banja Luka, Beograd i Nikšić: Centar modernih znanja, Resursni centar za specijalnu edukaciju i Centar za bezbjedonosna, sociološka i kriminološka istraživanja Crne Gore - "Defendologija", 2019.

Marković Krstić, S. and L. Milošević Radulović. Humanistička dimenzija obrazovanja mladih u kontekstu savremenih društvenih promena. Niš: Filozofski fakultet u Nišu, 2016.

Marković Krstić, S., L. Milošević Radulović, and N. Jovanović. "Univerzitetska nastava na Balkanu - između tradicionalnog i modernog". U Kulturne orijentacije studenata i kultura mira na Balkanu, priredile D. Zaharijevski, G. Đorić i G. Stojić, 183-202. Niš: Filozofski fakultet u Nišu, 2014.

Marković, Ž. D. Globalizacija i visokoškolsko obrazovanje. Niš: Državni univerzitet Novi Pazar i Univerzitet u Nišu, 2008.

Meadows, D. H. at al. The Limits to Growth. A Report for the Club of Rome's Project on the Predicament of Mankind. New York: Universe Books, 1972.

Mitrović, Lj. Sociološke marginalije na savremene teme. Novi Sad: Prometej, 2019.

Morin, E. Seven Complex Lessons in Education in the Future. Paris: UNESCO, 2002.

Reardon, R. E. "The Impact of Learning Culture on Worker Response to New Technology". Journal of Workplace Learning 22, 4 (2010): 201-211.

Reich, K. Konstruktivistische Didaktik. Weinheim und Basel: Beltz, 2008

Trivunović, B. "Komunikacione kompetencije univerzitetskih nastavnika". Pedagoška stvarnost LXIII, 2 (2017): 120-131.

Trnavac, N. and J. Đorđević. Pedagogija. Beograd: Naučna knjiga, 1995.

\section{DRUŠTVENA ULOGA I KOMPETENCIJE NASTAVNIKA U VISOKOM OBRAZOVANJU IZMEĐU TEORIJE I NASTAVNE PRAKSE}

Polazeći od toga da je visoko obrazovanje delatnost od posebnog društvenog interesa i pokretač razvoja i napretka društva, u teoriji i nastavnoj praksi se često postavljaju pitanja u vezi sa kvalitetom visokog obrazovanja $i$ mogućnostima njegovog unapređivanja. Kvalitet visokog obrazovanja $u$ pogledu povećanja njegove efikasnosti jedan je od zajedničkih ciljeva Bolonjske konvencije, odnosno aktuelnog reformskog procesa u evropskim državama. Determinisan je kvalitetom studijskog programa i kvalitetom nastavnog procesa, što zahteva kompetentnog nastavnika, pripremljenog za proces inoviranja nastavnih planova i programa, realizaciju $i$ unapređivanje nastavne prakse. $S$ obzirom na društveni značaj vaspitanja i obrazovanja, istraživanje društvene grupe koja obavlja radne zadatke u vaspitno-obrazovnoj delatnosti, kao i kvaliteta obavljanja nastavnog rada je od posebnog značaja. U radu su predstavljeni rezultati istraživanja studentske percepcije svojstva nastavnika u nastavnoj praksi visokog obrazovanja sagledanih kroz analizu ljudskih, stručnih $i$ 
The Social Role and Competencies of Teachers in Higher Education between Theory and Teaching Practice 59

pedagoških kvaliteta nastavnika, kvaliteta univerzitetske nastave/učenjai ishoda učenja/postignuća u učenju (zastupljenost teorijskih znanja, praktična primena znanja itd). Cilj rada je da se na osnovu rezultata tri empirijska istraživanja sa sociološkog stanovišta sagleda percepcija društvene uloge $i$ kompetencija nastavnika, kao i kvaliteta univerzitetske nastave iz ugla studentske omladine (2009. godine anketirano je 985 studenata 30 visokih škola strukovnih studija u Srbiji, 2012. godine 2208 studenata Univerziteta u Nišu (818), Univerziteta u Bitolju (804) i Univerziteta u Velikom Trnovu (586) i 2019. godine 374 studenata 13 fakulteta Univerziteta u Nišu). Empirijski nalazi pokazuju da su nastavnici, prema ocenama studenata, dobri stručnjaci koji predaju jasno, pregledno i naglašavaju bitno, ali su ipak njihova predavanja nedovoljno zanimljiva, a oni su često nepravedni i pristrasni. S obzirom na uočene razlike koje se odnose na kompetencije nastavnika u visokom obrazovanju, kvalitet $i$ ishode nastave/učenja, u radu su koncipirani ,modeli“ nastave/učenja za svaku zemlju obuhvaćenu istraživanjem (Srbiju, Makedoniju, Bugarsku). Na osnovu uočenog raskoraka između teorije $i$ nastavne prakse u radu se ističe potreba za novim naučnim istraživanjima u kontekstu reformskih procesa visokog obrazovanja uz kontinuirano redefinisanje njegovih ciljeva $i$ zadataka radi unapređivanja kvaliteta nastavnog procesa i nastavne prakse.

Ključne reči: visoko obrazovanje, kompetencije nastavnika, nastavna praksa, studentska omladina. 